\title{
PENINGKATAN PENDAPATAN ASLI DAERAH (PAD) MELALUI PENGEMBANGAN PARIWISATA KOTA MATARAM TAHUN 2018
}

\author{
Fakihi Rahman ${ }^{1}$ \\ ${ }^{1}$ Administrasi Bisnis Universitas Muhammadiyah Mataram
}

\begin{abstract}
ABSTRAK
Penelitian ini bertujuan untuk mengetahui bagaimana pengembangan pariwisata, dan untuk mengetahui jumlah kontribusi pajak pariwisata untuk PAD Kota Mataram serta kendala-kendala kontribusi pajak pariwisata. Peneliti menggunakan Pendekatan Kualitatif dengan Metode Deskriptif. Hasil penelitian menunjukkan bahwa Program pembangunan kepariwisataan dan rencana indikator yang dituangkan dalam Rencana Strategis Disbudpar Kota Mataram Tahun Anggaran 2016-2021 disusun dengan mengacu dan berpedoman pada Rencana Pembangunan Jangka Menengah Daeran (RPJMK) Kota Mataram Tahun 2016-2021. Dalam kontribusinya terhadap PAD Kota Mataram, pajak pariwisata tidak di pungut langsung pada setiap obyek wisata yang ada di Kota Mataram. Namun pajak pariwisata dapat dilihat melalui beberapa hasil pajak daerah yakni pajak hotel, pajak restoran, pajak hiburan dan pajak parkir. Dari ke empat jenis pajak tersebut, kontribusi terbesar terhadap PAD adalah pajak hotel dan yang paling rendah adalah pajak parkir. Kendala yang dihadapi dalam peningkatan kontribusi melalui pajak pariwisata adalah menurunnya minat wisatawan untuk mengunjungi pariwisata yang ada di kota mataram. Jika jumlah wisatawan menurun secara otomatis kontribusi pajak pariwisata akan menurun karna tinggi rendahnya kontribusi pajak pariwisata tergantung pada jumlah pengunjung wisatawan.
\end{abstract}

Kata Kunci: Pengembangan Pariwisata, Pajak Daerah, Pajak Pariwisata, Persentase Kontribusi Pajak Pariwisata

Terhadap Pajak Daerah. 


\section{PENDAHULUAN}

\subsection{Latar Belakang}

PAD merupakan sumber yang mempunyai arti penting karena mencerminkan kemandirian daerah. Pendapatan asli daerah merupakan usaha daerah guna memperkecil ketergantungan dalam mendapatkan dana dari pemerintah tingkat atas (subsidi).

Pembangunan pada umumnya dan pembangunan pariwisata pada khususnya perlu memperhatikan kondisi daerah serta faktor fisik dan non fisik. Hal ini untuk menghindari kerusakan lingkungan yang berlebihan, oleh karena itu pembangunan di sektor pariwisata hendaknya memperhatikan prinsip pembangunan yang berwawasan lingkungan dan pengembangan masyarakat local, sehingga pengembangan tersebut dapat meningkatkan pendapatan masyarakat dengan tetap mempertahankan kelestarian lingkungan dan nilai budaya.

Kota Mataram disebut dengan Kota Multi Etnik terkenal dengan berbagai ciri dan keunikannya yang tidak dimiliki kota-kota lain. Secara administratif meliputi 6 (enam) wilayah kecamatan, masing-masing kecamatan Ampenan, Sekarbela, Selaparang, Mataram, Cakranegara dan Sanubaya. Terdiri dari 50 kelurahan. Berdasarkan data terakhir dari Biro Pusat Statistik (BPS: 2010), penduduk Kota Mataram dihuni sekitar 402.843 jiwa. Selain itu juga dengan peninggalan sejarah yang masih berdiri tegak dan menjadi tonggak dan saksi berdirinya Kota Mataram serta destinasi objek wisata yang dimilikinya. Pesona objek wisata bahari, wisata budaya dan wisata sejarah Kota Mataram, memang tak ada habisnya.Beragam tempat wisata dan atraksibudayanya yang dapat nikmati oleh para wisatawan. Wisatawan tinggal memilih, ingin berwisata sejarah/budaya, berwisata bahari atau berwisata belanja Kota Mataram. Kota Mataram memiliki magnet tersendiri bagi para pelancong yang ingin menikmati nuansa wisata yang berbeda.

Dinas Kebudayaan dan Pariwisata Kota Mataram memiliki tantangan mendatangkan jumlah wisatawan ke Kota Mataram, membuat Pemerintah Kota Mataram harus meningkatkan promosi, dengan berbagai macam promosi yang lakukan oleh Dinas Kebudayaan dan Pariwisata Kota Mataram. Sebagai salah satu industri jasa, Pariwisata sangat berperan sebagai sumber penghasil devisa bagi Kota Mataram dan Nusa Tenggara Barat (NTB) secara umum. Sektor pariwisata ini mempunyai potensi baik untuk menciptakan kesempatan kerja dan kesempatan berusaha serta untuk meningkatkan dan memeratakan pendapatan masyarakat dan daerah.

Berdasarkan latar belakang penelitian diatas, penulis merumuskan masalah dalam bentuk pertanyaan penelitian sebagai berikut:

1. Bagaimana peningkatan PAD Kota Mataram melalui pengembangan pariwisata Kota Mataram?

2. Berapa persentase kontribusi pajak pariwisata terhadap Pendapatan Asli Daerah (PAD) Kota Mataram?

3. Apa Saja kendala-kendala dalam peningkatan pariwisata Kota Mataram?

\section{LANDASAN TEORI}

\subsection{Konsep Otonomi Daerah}

Menurut UU No. 22 Tahun 1999 Tentang Otonomi Daerah bahwa daerah otonom adalah kesatuan masyarakat hukum yang mempunyai batas tertentu berwenang mengatur dan mengurus kepentingan masyarakat setempat menurut prakarsa sendiri berdasarkan aspirasi masyarakat dalam ikatan Negara Kesatuan Republik Indonesia.

Sedangkan menurut UU No. 32 Tahun 2004 Tentang Otonomi Daerah bahwa daerah otonom adalah kesatuan masyarakat hukum yang mempunyai batas-batas wilayah yang berwenang mengatur dan mengurus urusan pemerintahan dan kepentingan masyarakat setempat menurut prakarsa sendiri berdasarkan aspirasi dalam sistem Negara Kesatuan Republik Indonesia.

\subsection{Pendapatan Asli Daerah (PAD)}

Pengertian pendapatan asli daerah berdasarkan Undang-Undang Nomor 33 Tahun 2004 tentang Perimbangan Keuangan Antara Pusat dan Daerah Pasal 1 angka 18 bahwa "Pendapatan asli daerah, selanjutnya disebut PAD adalah pendapatan yang diperoleh daerah yang dipungut berdasarkan peraturan daerah sesuai dengan peraturan perundang-undangan".

Pasal 157 UU No. 32 Tahun 2004 menyebutkan bahwa sumber pendapatan asli daerah terdiri atas pajak hasil daerah. Menurut UU No 34 Tahun 2000, jenis pajak kabupaten atau kota terdiri dari Pajak Hotel, Pajak Restoran, Pajak Hiburan, Pajak 
Reklame, Pajak Penerangan, Pajak Pengambilan Bahan Galian Golongan C, Pajak Parkir.

\subsection{Pariwisata}

Undang-undang Nomor 9 Tahun 1990 penyelenggaraan kepariwisataan dilaksanakan berdasarkan asas manfaat, usaha bersama dan kekeluargaan, adil dan merata, berperikehidupan dalam keseimbangan dan kepercayaan pada diri sendiri. Tujuan penyelenggaraan kepariwisataan yang ingin dicapai oleh UU ini adalah sebagai berikut :

1. Memperkenalkan, mendayagunakan, melestarikan, dan meningkatkan mutu obyek dan daya tarik wisata.

2. Memupuk rasa cinta tanah air dan meningkatkan persahabatan antar bangsa.

3. Memperluas dan meratakan kesempatan berusaha dan lapangan kerja.

4. Meningkatkan pendapatan nasional dalam rangka meningkatkankesejahteraan dan kemakmuran rakyat.

5. Mendorong pendayagunaan produksi nasional.

\subsection{Manfaat Pariwisata}

a. Meningkatnya kesempatan berusaha bagi penduduk area masyarakat yang linggal di sekitar objek wisata.

b. Sektor pariwisata dapat menyerap tenaga kerja yang dapat meningkatkan pendapatan dan kesejahteraan penduduk.

c. Pendapatan negara meningkat berupa pajak baik dari para wisatawan yang datang maupun pajak dari fasilitas sosial di daerah objek wisata, serta keuntungan dari pertukaran mata uang asing dengan mata uang Indonesia untuk keperluan para wisatawan.

d. Terpeliharanya kelestarian lingkungan hidup dan kebudayaan nasional. Dengan adanya pariwisa, masyarakat senantiasa menjaga keutuhan dan kelestarian objek wisata, baik objek wisata keindahan alam, bangunan-bangunan tradisional masyarakat.

\subsection{Pengembangan Obyek Wisata}

Menurut Salah Wahab dalam Wahyuni (2007:16) ada dua hal yang dapat ditawarkan kepada wisatawan sehingga menarik wisatawan untuk berkunjung ke suatu daerah tujuan wisata, dimana kedua hal tersebut dapat berupa alamiah atau buatan manusia, yaitu :
1. Sumber-Sumber Alam

a. Iklim: udara lembut, bersinar matahari, kering dan bersih.

b. Tata letak tanah dan pemandangan alam: dataran, pegunungan yang berpanorama indah, danau, sungai, pantai, bentuk-bentuk yang unik, pemandangan yang indah, air terjun, daerah gunung berapi, gua dan lainlain.

c. Unsur rimba: hutan-hutan lebat, pohonpohon langka, dan sebagainya.

d. Flora dan fauna: tumbuhan aneh, barangbarang beragam jenis dan warna, kemungkinan memancing, berburu dan bersafari foto binatang buas, taman nasional dan taman suaka binatang buas dan sebagainya.

e. Pusat-pusat kesehatan: sumber air mineral alam, kolam lumpur berkhasiat untuk mandi, sumber air panas alam untuk penyembuhan penyakit dan sebagainya.

2. Hasil karya buatan manusia yang ditawarkan

a. Yang berciri sejarah, budaya dan agama :

1) Monumen-monumen dan peninggalan-peninggalan bersejarah dari peradaban masa lalu

2) Tempat-tempat budaya seperti museum, gedung kesenian, tugu peringatan, perpustakaan, pentaspentas budaya rakyat, industri seni kerajinan tangan dan lain-lain.

3) Perayaan-perayaan tradisional, pameran-pameran, eksibisi, karnaval, upacaraupacara adat, ziarah-ziarah dan sebagainya.

4) Bangunan-bangunan raksasa dan biara-biara keagamaan

b. Prasarana-prasarana

1) Prasarana umum yang meliputi : Sistem penyediaan air bersih, kelistrikan, jalur-jalur lalu lintas, sistem pembangunan limbah, sistem telekomunikasi dan lain-lain.

2) Kebutuhan pokok pola hidup modern misalnya Rumah sakit, apotik, bank, pusat-pusat pembelanjaan, rumahrumah penata rambut, toko-toko bahan makanan, kantor-kantor pemerintahan (polisi, penguasa setempat, pengadilan dan sebagainya), toko-toko rokok, 
kedai-kedai obat, toko-toko kacamata, warung-warung surat kabar, toko-toko buku, bengkel-bengkel kendaraan bermotor, pompa-pompa bensin dan lain-lain.

3) Prasarana wisata yang meliputi Tempat-tempat penginapan wisatawan, bangunan-bangunan wisata sosial (desa wisata, tempat-tempat kemah, tempat-tempat karavan, pondok remaja dan sebagainya), rumah rumah katering (restoran, kedai-kedai minuman, rumah makan sederhana, warung-warung sate dan sebagainya), Agen-agen perjalanan, badan usaha perjalanan, usaha sewamenyewa kendaraan serta agen-agen yang mengatur ekskursi dan jalanjalan keliling kota, untuk menyampaikan informasi dan propaganda Kantor-kantor penerangan wisata di pintu-pintu masuk suatu negara, kota atau daerah tertentu, fasilitas sport untuk musim dingin dan panas, fasilitas perlengkapan sport darat dan air dan lain-lain.

c. Sarana pencapaian dan alat transportasi penunjang meliputi : pelabuhan udara, laut bagi negara-negara yang berbatasan dengan laut, sungai,atau danau multinasional, kereta api dan alat transportasi darat lainnya, kapal-kapal, sistem angkutan udara, angkutan di pegunungan dan lain-lain.

d. Sarana pelengkap : seperti halnya prasarana, maka sarana pelengkap ini berbeda menurut keadaan perkembangan suatu negara. Pada umumnya sarana ini meliputi gedung-gedung yang menjadi sumber produksi jasa-jasa yang cukup penting tetapi tidak mutlak diperlukan oleh wisatawan. Umumnya sarana pelengkap ini bersifat rekreasi dan hiburan seperti misalnya : gedung-gedung sandiwara, bioskop, kasino, nightclub, kedai-kedai minum, warung-warung kopi, klub-klub dan lain-lain

e. Pola hidup masyarakat yang sudah menjadi salah satu khasanah wisata yang sangat penting. Cara hidup bangsa, sikap, makanan dan sikap pandangan hidup, kebiasaannya, tradisinya, adat istiadatnya, semua itu menjadi kekayaan budaya yang menarik wisatawan ke negara mereka. Hal ini berlaku khususnya bagi negara-negara sedang berkembang yang masyarakat tradisionalnya berbeda dari masyarakat tempat wisatawan itu berasal. Modal dasar yang penting lainnya yakni sikap bangsa dari negara tersebut terhadap wisatawan; keramah tamahan, keakraban, rasa suka menolong dan tidak bertindak mengeksploitasi dan lain-lain.

\subsection{Strategi Promosi}

Setiap promosi yang dijalankan tentu memiliki berbagai tujuan yang khusus dilakukan untuk menarik konsumen. Tujuan utama dari kegiatan promosi menurut Basu Swastha dan Irawan (1983: 353), antara lain:

1) Modifikasi Tingkah Laku

Orang-orang melakukan komunikasi selalu mempunyai beberapa alasan, misalnya mencari kesenangan, mencari bantuan, memberikan pertolongan atau instruksi, memberikan informasi, mengemukakan ide dan pendapat. Promosi dari segi lain, berusaha merubah tingkah laku, pendapat danmemperkuat tingkah laku yang ada.

2) Memberitahu Kegiatan promosi dapat dilakukan untuk memberitahu pasar yang dituju tentang penawaran perusahaan. Sebelum mereka mengetahui produk dan apa faedahnya maka mereka tidak akan membeli barang atau jasa tersebu. Promosi yang bersifat memberi tahu ini juga penting bagi konsumen karena dapat membantu dalam pengambilan keputusan untuk membeli.

3) Membujuk

Promosi yang bersifat membujuk ini diarahkan untuk mendorong pembelian. Sifat membujuk ini akan menjadi dominan jika produk yang bersangkutan mulai memasuki tahap pertumbuhan didalam siklus kehidupan.

4) Mengingatkan

Tujuan promosi yang bersifat mengingatkan dilakukan untuk mempertahankan mrek produk di hati masyarakat dan perusahaan berusaha untuk mempertahankan pembeli yang ada. 


\subsection{Media Promosi (Promotion Mix)}

Berkaitan dengan promosi maka akan berkaitan dengan berbagai kegiatan dan model yang memiliki berbagai unsur yang dapat dikombinasikan, kondisi ini dinamakan media promosi(promotional mix). Menurut Basu Swastha dan Irawan (1983: 349)Promotional mix adalah kombinasi strategi yang paling baikdari variabel-variabel periklanan, personal selling dan alat promosi yang lain, yang semuanya direncanakan untukmencapai tujuan program penjualan.Keterangan variabel promotional mixmenurut Basu Swasthadan Irawan (1983: 349) di atas, antara lain:

\section{Periklanan}

Adalah bentuk presentasi dan promosi non pribadi tentang ide,barang, dan jasa yang dibayarkanoleh sponsor tertentu.

\section{Personal Selling}

Adalah presentasi lisan dalam suatu percakapan dengan satu calonpembeli atau lebih yang ditujukan untuk menciptakan penjualan. 3. Publisitas

Adalah pendorongan permintaan secara non pribadi untuk suatuproduk, jasa, atau ide dengan menggunakan beritakomersildidalam media massa dan sponsor tidak dibebanisejumlah bayaran secara langsung.

4. Promosi Penjualan

Adalah kegiatan pemasaran, selain personal selling, periklanandan publisitas yang mendorong pembelian konsumen danefektifitas pengecer. Kegiatan-kegiatan tersebut antara lain:peragaan, pertunjukan atau pameran, dan demonstrasi.

\subsection{Kaitan Pariwisata dan Strategi Promosi}

Nyoman S. Pendit (2002: 34) merumuskan pengertian pariwisata dalam arti modern yaitu pariwisata merupakan fenomena dari jaman sekarang yang didasarkan atas kebutuhan akan kesehatan dan pergantian hawa, penilaian yang sadar dan menumbuhkan (cinta) terhadap keindahan alam dan pada khususnya disebabkan oleh bertambahnya pergaulan berbagai bangsa dan kelas masyarakat manusia sebagai hasil daripada perkembangan perniagaan, industri, perdagangan serta penyempurnaan daripada alat-alat pengangkutan.
Menurut David W. Cravens (1998:77), Strategi promosi adalah suatu perencanaan, implementasi, dan pengendalian komunikasi dari suatu organisasi kepada para konsumen dan sasaran lainnya. Dengan menggunakan strategi maka suatu perusahaan dapat merencanakan bagaimana produk atau jasa bisa bersaing dengan yang lain. dan memposisikan produknya di benak konsumen.

Jadi pariwisata dan strategi promosi mempunyai keterkaitan, karena dengan strategi promosi yang baik dan cocok akan memberikan pengaruh yang baik bagi kepariwisataan dalam menarik wisatawan yang berkunjung dan sebaliknya strategi promosi yang kurang terhadap pariwisata akan berdampak pada menurunnya wisatawan yang berkunjung.

\section{METODE PENELITIAN}

\subsection{Metode Penelitian}

Adapun metode yang digunakan dalam penelitian ini adalah metode kualitatif, dengan model deskriptif, berhubungan dengan nilai misalnya adanya kenyataan sebagai keutuhan pada konteks dari suatu keutuhan tersebut (Moleong, 2005;6). Dalam penelitian ini, penulis memilih kantor Dinas Kebudayaan dan Parwisata Kota Mataramsebagai lokasi penelitian. Penetapan lokasi didasarkan pada pertimbangan bahwa lokasi tersebut lokasi yang sangat tepat untuk memperoleh data atau informasi yang akurat dan relevan dengan permasalahan penelitian yang ada.

Dalam kegiatan penelitian yang menjadi sumber informasi adalah para informan yang berkompeten dan mempunyai relevansi dengan penelitian. Dalam penelitian ini peneliti menggunakan menggunakanpurposive sampling, adapun yang menjadi informan dalam penelitian ini adalah staf-staf yang bersangkutan pada kantor Dinas Kebudayaan dan Pariwisata, sengan teknik pengumpulan data berupa observasi, wawancara, dan dokumentasi

Dalam penelitian ini, tehnik analisis data yang akan digunakan adalah tehnik kualitatif, dengan mengikuti alur kegiatan miles dan huberman, (1984) dalam (Sugiyono, 2013 : 246 252) yang terdiri dari beberpa tahap, yakni :

1. Data Reduksi (Data Reduction), dengan peralatan elektronik seperti komputer mini, 
dengan memberikan kode pada aspek-aspek tertentu.

2. Penyajian Data (Data Display), dalam hal ini yang digunakan untuk penyajian data dalam penelitian kualitatif adalah dengan teks yang bersifat naratif.

3. Penarikan

(Verification/Conclusion Drowing) dan verifikasi.

\section{HASIL PENELITIAN DAN PEMBAHASAN}

Potensi yang di miliki kota mataram dapat menjadi produktivitas yang bermanfaat apabila potensi tersebut khususnya pada pariwisata dapat dimanfaatkan dengan sebaik-baiknya. Salah satu pemanfaatan potensi wisata yang dapat dilakukan yaitu pengembangan sektor pariwisata khususnya kota mataram, hal ini dilakukan untuk menarik wisatawan baik itu wisatawan lokal maupun mancanegara terhadap tempat wisata kota mataram dapat meningkat.

Peningkatan jumlah wisatawan yang berkunjung ketempat-tempat wisata di kota mataram tentunya akan berpengaruh besar terhadap peningkatan pendapatan asli daerah kota mataram. Sarana prasarana yang telah di sediakan oleh pemerintah kota mataram juga menjadi salah satu faktor dalam meningkatkan jumlah kunjungan wisatawan di kota mataram. Beberapa sarana prasarana yang di maksud di antaranya : pertama, Hotel : merupakan sarana yang di sajikan sebagai tempat persinggahan para wisatawan yang berkunjung di kota mataram. Kedua, Restaurant : merupakan tempat dimana para wisatawan dapat menikmati kuliner khas daerah yang terdapat di kota mataram. Ketiga, Tempat hiburan atau berbelanja salah satunya adalah Mall.

Dengan meningkatnya kunjungan wisatawan dan penggunaan sarana prasarana di kota mataram tentunya dipastikan pendapatan asli daerah (PAD) kota mataram meningkat karna dapat di lihat dari penyajian fasilitas yang disediakan oleh pemerintah daerah dan karna fasilitas tersebut tidak luput dari adanya pengambilam/pemungutan pajak yang sudah ditentukan oleh pemerintah daerah.

Semua instansi memiliki harapan tujuan yang diharapkan akan dicapai kesemuanya itu dituangkan dalam visi misi dan tujuan instansi, hal ini juga berlaku untuk kota Mataram. Adapun visi, misi dan tujuannya antara lain :

\subsection{VISI, Misi dan Tujuan Kota Mataram}

Visi pembangunan Kota Mataram Tahun 2011-2015 adalah "Terwujudnya Kota Mataram yang Maju, Religius dan Berbudaya”. Untuk mencapai Visi "Terwujudnya Kota Mataram yang Maju,Religius dan Berbudaya", Pemerintah Kota Mataram telah menetapkan lima Misi yaitu :

a. Meningkatkan rasa "AMAN" masyarakat Kota Mataram yang ditunjukkan dengan kehidupan yang kondusif, dinamis, dan harmonis dilandasi nilai agama dan budaya.

b. Meningkatkan kualitas Sumber Daya Manusia yang handal dan religious untuk mendorong daya saing daerah.

c. Memberdayakan ekonomi rakyat berbasis potensi lokal yang berkelanjutan untuk meningkatkan kemandirian daerah.

d. Meningkatkan kualitas pelayanan publik dan pemenuhan kebutuhan dasar masyarakat berdasarkan prinsip tata pemerintahan yang baik (Good Governance).

e. Meningkatkan kualitas dan kuantitas sarana dan prasarana perkotaan.

Tujuan pembangunan Kota Mataram dalam pencapaian Visi, ditetapkan sebagai berikut :

a. Menciptakan suasana Kota Mataram yang kondusif, dinamis dan harmonis yang dilandasi nilai agama dan budaya.

b. Mewujudkan sumberdaya manusia yang berkualitas.

c. Meningkatkan kesejahteraan masyarakat.

d. Meningkatkan kapasitas dan kemandirian ekonomi daerah

e. Meningkatkan investasi.

f. Peningkatan kemitraan antara pemerintah, masyarakat dan swasta dalam pelayanan publik dan pemenuhan kebutuhan dasar masyarakat.

g. Peningkatan kualitas pelayanan publik berdasarkan prinsip tata pemerintahan yang baik (Good Governance).

h. Perluasaan akses masyarakat terhadap pelayanan pendidikan, Kesehatan, air bersih, persampahan, sanitasi, perijinan, transportasi, kependudukan dan catatan sipil.

i. Mengurangi luas wilayah genangan dan abrasi di wilayah kota.

Meningkatkan kualitas lingkungan Padat, Kumuh dan Miskin (PAKUMIS). 
j. Meningkatkan media ekspresi dan ruang publik,

k. Mewujudkan pembangunan berwawasan lingkungan dan berkelanjutan.

\subsection{Potensi Wisata Kota Mataram}

A.Hari Karyono (1997: 28) mengungkapkan bahwa "Agar suatu daerah tujuan wisata mempunyai daya tarik maka harus mempunyai 3 syarat daya tarik yaitu : ada sesuatu yang bisa dilihat (something to see), ada sesuatu yang dapat dikerjakan (something to do) dan ada sesuatu yang bisa dibeli (something to buy)".

Potensi wisata yang dimiliki oleh Kota Mataram secara garis besar terdiri dari potensi alam, potensi non alam. Berikut adalah potensi wisata yang dimiliki oleh Kota Mataram, disajikan dalam bentuk tabel dibawah ini :

Tabel 4.2

\begin{tabular}{|c|c|c|}
\hline No & $\begin{array}{l}\text { Nama Wisata No } \\
\text { nAlam }\end{array}$ & Jenis Wisata \\
\hline 1. & Taman Mayura & $\begin{array}{l}\text { Wisata budaya, Wisata } \\
\text { Sejarah, Taman Rekreasi }\end{array}$ \\
\hline 2. & Makam Bintaro & Taman Sejarah \\
\hline 3. & Makam Van Ham & Taman Sejarah \\
\hline 4. & Pasar Mandalika & Pasar Induk Tradisional \\
\hline 5. & $\begin{array}{l}\text { Taman } \\
\text { Gora }\end{array}$ & $\begin{array}{l}\text { Taman Rekreasi, Arena } \\
\text { bermain dan Olahraga, } \\
\text { Wisata Kuliner }\end{array}$ \\
\hline 6. & Mataram Mall & Wisata Belanja \\
\hline 7. & $\begin{array}{lr}\text { Sentra } & \text { Industri } \\
\text { Kotak } & \text { Antik }\end{array}$ & Pasar Seni \\
\hline
\end{tabular}

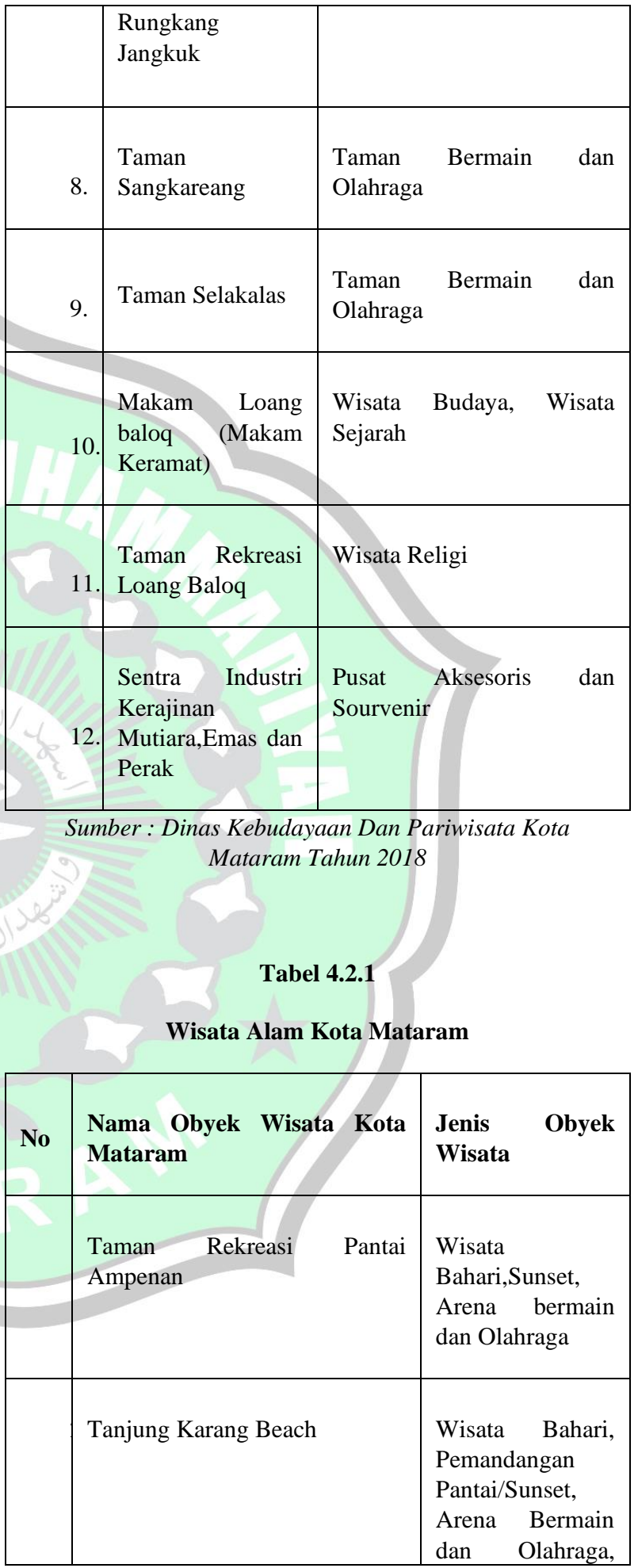




\begin{tabular}{|c|c|}
\hline & Wisata Kuliner \\
\hline Pantai Loang Baloq & $\begin{array}{l}\text { Wisata Bahari, } \\
\text { Sunset, Arena } \\
\text { Bermain dan } \\
\text { Olahraga, } \\
\text { Pemandangan, } \\
\text { Wisata Kuliner }\end{array}$ \\
\hline Kuranji Beach & $\begin{array}{lr}\text { Wisata } & \text { Bahari, } \\
\text { Sunset, } & \text { Arena } \\
\text { bermain } & \text { dan } \\
\text { Olahraga, } & \text { Wisata } \\
\text { Kuliner } & \end{array}$ \\
\hline Pantai Gading & $\begin{array}{lr}\text { Wisata } & \text { Bahari, } \\
\text { Sunset, } & \text { Arena } \\
\text { bermain } & \text { dan } \\
\text { Olahraga, } & \text { Wisata } \\
\text { Kuliner } & \end{array}$ \\
\hline
\end{tabular}

Sumber: Dinas Kebudayaan Dan Pariwisata Kota Mataram Tahun 2018

\subsection{Pembahasan}

\subsubsection{Pengembangan Pariwisata Kota Mataram}

Pengembangan pariwisata di Kota Mataram merupakan langkah strategis yang ditetapkan oleh pemerintah kota untuk meningkatkan taraf hidup masyarakat dan peningkatan Pendapatan Asli Daerah. Keputusan tersebut didasarkan pada pertimbangan bahwa Kota Mataram memiliki potensi yang cukup dalam di bidang kepariwisataan seperti obyek dan dayatarik wisata yang didukung oleh prasarana wisata, sarana wisata, infrastruktur danmasyarakat atau lingkungan. Hal tersebut sesuai dengan pendapat Gamal Suwantoro (2004: 19) dikutip oleh Tri Wahyuni, yang menjelaskan bahwa "Unsur pokok yang harus mendapat perhatian guna menunjang pengembangan pariwisata di daerah tujuan wisata yang menyangkut perencanaan, pelaksanaan, pembangunan dan pengembangannya meliputi lima unsur, yaitu obyek dan daya tarik wisata, prasarana wisata, sarana wisata, tata laksana (infrastruktur) dan masyarakat (lingkungan).

Program pembangunan kepariwisataan dan rencana indikator yang dituangkan dalam Rencana Strategis Disbudpar Kota Mataram Tahun Anggaran 2016-2021 disusun dengan mengacu dan berpedoman pada Rencana Pembangunan Jangka Menengah Daerah (RPJMK) Kota Mataram Tahun 2016-2021.

Untuk mewujudkan dan guna memberikan arah serta tujuan yang ingin dicapai, dipandang perlu untuk memberikan fokus terhadap program yang akan dilaksanakan maupun untuk menumbuhkan partisipasi semua pihak, maka ditetapkan beberapa program yang menjadi prioritas utama Pariwisata dan Budaya. Program tersebut antara lain:

1. Program Pengembangan Pemasaran Pariwisata, yang menitik beratkan pada kegiatan Promosi Pariwisata di Dalam dan di Luar Daerah.

2. Program Pengembangan Destinasi Pariwisata, yang menitik beratkan pada kegiatan penataan dan pembangunan sarana dan prasarana pariwisata serta meningkatkan PAD melalui proses pemberian izin usaha pariwisata.

3. Program Pengelolaan Keragaman Budaya Daerah, yang menitikberatkan pada kegiatan pembinaan dan pengembangan kesenian serta pelestarian Adat Budaya Daerah.

Agar pengembangan kepariwisataan dapat berhasil, maka Dinas Pariwisata dan Kebudayaan Kota Mataram perlu melibatkan berbagai pihak melalui upaya kerjasama antara pemerintah, masyarakat dan pelaku usaha jasa pariwisata. Keberhasilan pengembangan pariwisata di Kota Mataram dapat diukur dengan tingkat kunjungan wisatawan yang datang ke Kota Mataram dan jumlah pendapatan dari obyek wisata. Dengan terjadinya peningkatan jumlah kunjungan wisatawan dan pendapatan, diharapkan akan meningkatkan pendapatan masyarakat melalui perluasan lapangan kerja serta meningkatkan Pendapatan Asli Daerah.

Dengan adanya pengembangan khususnya pada pariwisata di kota mataram dan yang sudah dijelaskan pada teori di atas bahwa dalam pengembangan pariwisata dibutuhkan strategi yang ditetapkan oleh pemerintah tentunya 
Pengembangan pariwisata di kota mataram berkembang dengan baik, melihat apa yang menjadi program pemerintah daerah dan penerapannya dari segi pemasaran (promosi), penataan dan pembangunan, serta pemberdayaan seni dan budaya daerah yang masih kuat. Dengan ini, untuk mempe rkuat penelitian peneliti dalam penelitian peningkatan Pendapatan Asli Daerah (PAD) melalui Pengembangan Pariwisata Kota Mataram menunjukkan bahwa apa yang menjadi program pemerintah yang sudah di jelaskan di atas terlaksana dengan baik, dengan adanya fasilitas-fasilitas dalam setiap obyek wisata, seperti penyediaan tempat sampah untuk membuang sampah dan secara tidak langsung memberi pemahaman kepada masyarakat akan menjaga lingkungan wisata, berugak untuk tempat beristirahatnya pengunjung serta sebagai tempat pengunjung untuk menikmati pesona alam dan kuliner khas yang sudah tersedia di tempat wisata tersebut, arena bermain yang tidak hanya dapat di nikmati oleh anak-anak tetapi juga bagi kaum remaja bahkan juga orang dewasa, dan penyediaan UKM yang menyediakan berbagai macam kuliner khas lombok dan kuliner daerah.tersebut. Dengan ini tidak lain untuk meningkatkan pengunjung untuk berkunjung ke obyek wisata ini yang didominasi kunjungan wisatawan lokal baik itu dari daerah wisata itu sendiri maupun daerah luar obyek wisata tersebut, tetapi tidak sedikit pula wisatawan mancanegara yang berkunjung ke obyek wisata tersebut. Peningkatan pengunjung pada obyek wisata ini biasanya terjadi pada hari libur tetapi pada hari-hari biasa tidak jauh berbeda dengan hari libur. Obyek wisata loang balok contohnya kunjungan wisatawan bisa mencapai 1000-2000 pengunjung perbulan dengan melihat pemasukan dari tiket yang habis terjual (ujar Burhan selaku penjaga sekaligus penjualan tiket). Beda halnya dengan obyek wisata non alam (Taman Mayure Dan Taman Sangkareang), peneliti tidak bisa melampirkan angka kunjungan dari obyek wisata ini karna peneliti tidak menemukan penjualan tiket masuk yang dapat membantu dalam penyimpulan data kunjungan pada obyek ini.

Obyek wisata ini, tidak hanya berdampak pada tingkat kunjungan wisatawan tetapi juga berdampak pada peningkatan pendapatan masyarakat sekitar obyek wisata, sekaligus meningkatkan perekonomian masyarakat yang tinggal pada daerah wisata tersebut.
Dari beberapa hasil baik itu dari wawancara maupun observasi beberapa obyek wisata dapat disimpulkan bahwa, dalam pengembangan pariwisata perlu adanya strategi yang di tetapkan oleh pemerintah untuk lebih memudahkan dalam menjalankan program-program yang di rencanakan ataupun yang sudah ada. Tidak hanya itu, penataan dan pembangunan sarana prasarana perlu dilakukan baik itu dari segi obyek wisata dan fasilitas pendukung seperti : pembangunan fasilitas pada setiap obyek wisata, pelayanan, perizinan, serta penyediaan hotel, restoran, prastruktur jalan yang memadai, dan sebagainya. Dengan adanya hal tersebut dengan otomatis tingkat kunjungan wisatawan baik itu wisatawan lokal maupun mancanegara akan mengalami peningkatan dan tentunya meningkatkan Pendapatan Asli Daerah kota mataram dari sektor pajak pariwisata terhadap pajak daerah kota mataram.

Tingkat kunjungan tidak hanya berdampak pada peningkatan pajak pariwisata yang secara otomatis juga dapat meningkatkan pajak daerah melalui pariwisata tersebut tetapi, sangat berpengaruh juga terhadap perekonomian masyarakat sekitar dari peningkatan pendapatan masyarakat melalui adanya UKM-UKM di obyek wisata.

Dalam hal ini, melihat dari jumlah kunjungan peneliti menyimpulkan untuk sementara bahwa, dari sekian obyek wisata yang ada di kota mataram peneliti mengambil sample obyek wisata pantai loang balok, taman mayura, taman sangkareang, menyimpulkan obyek wisata yang menjadi unggulan yaitu wisata alam yang dimana data kunjungan dapat di lihat dari penjualan tiket masuk, sedangkan obyek wisata non alam peneliti tidak menemukan data karna tidak di kenakannya tiket masuk pada obyek wisata non alam tersebut.

\subsubsection{Presentase Kontribusi Pajak Pariwisata Terhadap PAD Kota Mataram}

Sebagaimana yang telah dibahas pada bab sebelumnya bahwa penelitian ini akan membahas tentang berapa persentase kontribusi yang dihasilkan pariwisata Kota Mataram terhadap PAD kota Mataram. Tetapi setelah melakukan penelitian, baik pada kantor Dinas Pendapatan Daerah maupun pada Dinas Kebudayaan dan Pariwisata, sektor pariwisata tidak dipungut pajak untuk Pendapatan Asli Daerah Kota Mataram. Dari pernyataan 
tersebut, peneliti menanyakan bagaimana peningkatan pendapatan asli daerah yang diperoleh dari retribusi pariwisata melalui setiap obyek wisata khususnya kota mataram yang dimana peneliti mengetahui bahwa setiap obyek wisata adanya pemungutan yang berupa tiket masuk, parkir, dan sebagainya. Tetapi jawaban atas pertanyaan peneliti tidak diklarifikasi oleh pihak Dispenda Kota Mataram karena pihaknya tidak tahu-menahu tentang adanya pemungutan yang berupa tiket masuk, parkir, dan sebagainya, ataupun pengelolaan obyek wisata tersebut.

Dari pernyataan di atas dapat disimpulkan bahwa tidak ada pungutan pajak oleh pemerintah daerah. Pungutan pajak parkir dan tiket masuk suatu obyek wisata yang ada di Kota Mataram sematamata untuk menggaji pihak pengelola obyek wisata, sekaligus meningkatkan kesejahteraan masyarakat sekitar obyek wisata.

Tabel PAD dan Realisasi Pajak Hotel yang di kelola Dinas Pendapatan Kota Mataram

\begin{tabular}{|c|c|c|c|}
\hline Tahun & Target PAD & Realisasi & \% \\
\hline 2013 & 3.698 .400 .000 & 4.964 .855 .752 & 134.24 \\
\hline 2014 & 5.200 .000 .000 & 5.929 .938 .014 & 114.06 \\
\hline 2015 & 9.000 .000 .000 & 10.355 .439 .068 & 115.06 \\
\hline 2016 & 9.500 .000 .000 & 10.791 .412 .715 & 113.59 \\
\hline 2017 & 10.500 .000 .000 & 12.412 .894 .021 & 118.22 \\
\hline Jumlah & $\mathbf{3 7 . 8 9 8 . 4 0 0 . 0 0 0}$ & $\mathbf{4 4 . 4 5 4 . 5 3 9 . 5 7 0}$ & $\mathbf{1 1 7 , 2 9}$ \\
& & & \\
\hline
\end{tabular}

Sumber: Dinas Pendapatan Kota Mataram Tahun 2018

Dari tabel PAD dan Realisasi Pajak Hotel yang di kelola Dinas Pendapatan Kota Mataram diatas, dapat di jelaskan bahwa target PAD dari tahun ke tahun mengalami peningkatan. Pada tahun 2013, target PAD untuk pajak hotel adalah Rp. 3.698.400.000dan terus meningkat hingga tahun 2017 mencapai Rp. 10.500.000.000. Meski demikian, realisasi pajak hotel di setiap tahun selalu melebihi target PAD yang telah ditentukan meskipun target setiap tahunnya tetap meningkat. Dengan demikian jumlah PAD menunjukkan pada Rp. 37.898 .400 .000 dan realisasinya Rp. 44.454.539.570.
Tabel PAD dan Realisasi Pajak Restoran yang di kelola Dinas Pendapatan Kota Mataram

\begin{tabular}{|c|c|c|c|}
\hline Tahun & Target PAD & Realisasi & \% \\
\hline 2013 & 6.376 .248 .000 & 7.058 .184 .942 & 110.69 \\
\hline 2014 & 7.300 .000 .000 & 7.525 .423 .164 & 103.09 \\
\hline 2015 & 7.800 .000 .000 & 9.603 .797 .073 & 123.13 \\
\hline 2016 & 9.500 .000 .000 & 10.831 .060 .378 & 114.01 \\
\hline 2017 & 10.500 .000000 & 11.438 .711 .583 & 108.94 \\
\hline Jumlah & $\mathbf{4 1 . 4 7 6 . 2 4 8 . 0 0 0}$ & $\mathbf{4 6 . 4 5 7 . 1 7 7 . 1 4 0}$ & $\mathbf{1 1 2 , 0 0}$ \\
\hline
\end{tabular}

Sumber: Dinas Pendapatan Kota Mataram Tahun 2018

Dari tabel PAD dan Realisasi Pajak restoran yang di kelola Dinas Pendapatan Kota Mataram diatas, dapat di jelaskan bahwa target PAD dari tahun ke tahun me ngalami peningkatan. Pada tahun 2013, target PAD untuk pajak restoran adalah Rp. 6.376.248.000 dan terus meningkat hingga tahun 2017 mencapai Rp. 10.500.000.000. Meski demikian, realisasi pajak restoran di setiap tahun selalu melebihi target PAD yang telah ditentukan meskipun target setiap tahunnya tetap meningkat. Dengan demikian jumlah PAD menunjukkan pada Rp. 41.476.248.000 dan realisasinya $\mathrm{Rp}$. 46.457.177.140.

Tabel PAD dan Realisasi Pajak Hiburan yang di kelola Dinas Pendapatan Kota Mataram

\begin{tabular}{|c|c|c|c|}
\hline Tahun & Target PAD & Realisasi & \% \\
\hline 2013 & 250.000 .000 & 352.129 .000 & 140.85 \\
\hline 2014 & 317.320 .000 & 398.541 .661 & 124.63 \\
\hline 2015 & 319.000 .000 & 486.588 .295 & 139.03 \\
\hline 2016 & 600.000 .000 & 721.642 .282 & 120.27 \\
\hline 2017 & 1.000 .000 .000 & 1.466 .622 .671 & 146.66 \\
\hline Jumlah & $\mathbf{2 . 4 8 6 . 3 2 0 . 0 0 0}$ & $\mathbf{3 . 4 2 5 . 5 2 3 . 9 0 9}$ & $\mathbf{1 3 7 , 7 7}$ \\
& & & \\
\hline
\end{tabular}


Sumber: Dinas Pendapatan Kota Mataram Tahun 2018 Dari tabel PAD dan Realisasi Pajak hiburan yang di kelola Dinas Pendapatan Kota Mataram diatas, dapat di jelaskan bahwa target PAD dari tahun ke tahun mengalami peningkatan. Pada tahun 2013, target PAD untuk pajak hiburan adalah Rp. 250.000.000 dan terus meningkat hingga tahun 2017 mencapai Rp. 1.000.000.000. Meski demikian, realisasi pajak hiburan di setiap tahun selalu melebihi target PAD yang telah ditentukan meskipun target setiap tahunnya tetap meningkat. Dengan demikian jumlah PAD menunjukkan pada Rp.2.486.320.000dan realisasinya Rp. 3.425.523.909.

Tabel 4.3.2.4 PAD dan Realisasi Pajak Parkiryang di kelola Dinas Pendapatan Kota Mataram

\begin{tabular}{|c|c|c|c|}
\hline Tahun & Target PAD & Realisasi & $\%$ \\
\hline 2013 & 765.000 .000 & 811.364 .886 & 106.05 \\
\hline 2014 & 375.000 .000 & 395.712 .777 & 105.52 \\
\hline 2015 & 400.000 .000 & 443.836 .886 & 110.96 \\
\hline 2016 & 425.000 .000 & 587.903 .160 & 138.33 \\
\hline 2017 & 650.000 .000 & 660.157 .990 & 101.56 \\
& & & \\
\hline Jumlah & $\mathbf{2 . 6 1 5 . 0 0 0 . 0 0 0}$ & $\mathbf{2 . 8 9 8 . 9 7 5 . 6 9 9}$ & \\
\hline \multicolumn{4}{|l}{ Sumber: Dinas Pendapatan Kota Mataram Tahun 2018 }
\end{tabular}

Dari tabel PAD dan Realisasi Pajak parkir yang di kelola Dinas Pendapatan Kota Mataram diatas, dapat di jelaskan bahwa target PAD dari tahun ke tahun mengalami peningkatan, tetapi tidak untuk tahun 2014. Dapat di lihat bahwa pada tahun 2013, target PAD mencapai Rp.765.000.000. Dan pada tahun 2014 target PAD menurut mencapai Rp. 375.000.000. meski demikian, target PAD untuk tahun 2015-2017 mengalami peningkatan dan realisasi retribusi tetap mencapai lebih dari target PAD yang ditetapkan. Dengan demikian jumlah PAD menunjukkan pada Rp.2.615.000.000dan realisasinya Rp. 2.898.975.699

Jadi, dari keempat Tabel TargetPAD dan Realisasi Pajak yang di kelola Dinas Pendapatan Kota Mataram di atas dapat disimpulkan bahwa keempat jenis pajak yang dikategorikan Dispenda untuk pajak pariwisata tergolong sangat tinggi karena rata-rata melebihi target PAD setiap tahunnya. Jadi dapat dikatakan bahwa keempat tersebut sangat berperan dalam membantu meningkatkan PAD Kota Mataram.

Dari keempat pajak di atas, target dan realisasi pajak yang mencapai angka maksimum terdapat pada tahun 2017, di uraikan sebagai berikut

Tabel Target dan Realisasi Pajak

Daerah yang dikelola Dinas Pendapatan Kota Mataram Tahun 2017

\begin{tabular}{|c|c|c|c|}
\hline $\begin{array}{c}\text { Jenis } \\
\text { Pajak }\end{array}$ & Target & Realisasi & $\%$ \\
\hline Hotel & 10.500 .000 .000 & 12.412 .894 .021 & 118.22 \\
\hline Restoran & 10.500 .000 .000 & 11.438 .711 .582 & 108.94 \\
\hline Hiburan & 1.000 .000 .000 & 1.466 .622 .671 & 146.66 \\
\hline Parkir & 650.000 .000 & 660.156 .990 & 101.55 \\
\hline Jumlah & $\mathbf{2 2 . 6 5 0 . 0 0 0 . 0 0 0}$ & $\mathbf{2 5 . 9 7 8 . 3 8 5 . 2 6 4}$ & $\mathbf{1 1 4 , 6 9}$ \\
\hline
\end{tabular}

Sumber : Dinas Pendapatan Kota Mataram Tahun 2018

Dari tabel di atas, dapat simpulkan bahwa pada tahun 2017, angka target tertinggi untuk PAD kota Mataram adalah pajak hotel dan pajak restoran yakni mencapai Rp. 10.500.000.000. Kemudian target PAD untuk pajak hiburan mencapai Rp. 1.000.000.000, dan Rp. 650.000.000 untuk target PAD pajak parkir. Selanjutnya dapat di lihat bahwa angka realisasi tertinggi dari ke empat jenis pajak di atas, meskipun target PAD untuk pajak restoran sama dengan pajak hotel, realisasi menunjukkan bahwa pajak Hotel adalah yang paling tinggi yakni Rp. 12.412.894.021 dengan efektifitas 118,22\% dan untuk pajak restoran mencapai realisasi $\mathrm{Rp}$. 11.438.711.582 dengan efektifitas mencapai 108,94 \%. Rp. 1.466.622.671 untuk pajak hiburan dengan efektifitas 146,66 \% realisasi paling rendah ditunjukkan oleh realisasi untuk pajak parkir yakni Rp. 660.156.990 dengan efektifitas 101,55 \% . Meski demikian, target dan realisasi untuk PAD Kota Mataram melalui ke empat pajak di atas mengalami peningkatan secara terus menerus dari tahun-tahun sebelumnya.

4.3.3 Kontribusi PAD Kota Mataram Melalui Masing-Masing Pajak Pariwisata Dari Unsur Pajak Daerah. 
Dari data persentase kontribusi PAD yang di atas peneliti belum menemukan kontribusi PAD dari masing-masing pajak pariwisata yang memberikan berapa persentasi terhadap PAD Kota Mataram. Oleh karnanya peneliti mencoba melampirkan data-data atau perhitungan persentasi kontribusi dari masing-masing pajak pariwisata dari pajak daerah. Berikut tabel hasil data kontribusi PAD Kota Mataram melalui masing-masing pajak pariwisata dari unsur pajak daerah.

Tabel 4.3.3.1 Kontribusi PAD Kota Mataram Dari Sektor Pajak Perhotelan

\begin{tabular}{|c|r|r|c|}
\hline Tahun & Jumlah PAD & Realisasi & $\%$ \\
\hline 2013 & 42.171 .198 .442 & 4.964 .855 .752 & 11,77 \\
\hline 2014 & 46.343 .206 .065 & 5.929 .938 .014 & 12,79 \\
\hline 2015 & 60.449 .655 .086 & 10.355 .439 .068 & 17,13 \\
\hline 2016 & 66.971 .429 .671 & 10.791 .412 .715 & 16.11 \\
\hline 2017 & 66.267 .245 .420 & 12.412 .894 .021 & 18.73 \\
\hline Jumlah & 282.202.734.684 & $\mathbf{4 4 . 4 5 4 . 5 3 9 . 5 7 0}$ & $\mathbf{1 5 . 7 5}$ \\
\hline \multicolumn{3}{|c|}{ Sumber : Dinas Pendapatan Kota Mataram Tahun 2018 } \\
\hline
\end{tabular}

Pada tabel di atas menunjukkan PAD Kota

Mataram pada tahun 2013 sebesar Rp.42.171.198.442, sehingga untuk pajak perhotelan tahun 2013 sebesar Rp.4.964.855.752. Artinya pajak pariwisata memberikan kontribusi $11,77 \%$ dari 9 sektor pajak terhadap PAD Kota Mataram. Pada tahun 2014 dan 2015 PAD untuk pajak perhotelan meningkat sebesar Rp. 46.343.206.065 untuk tahun 2014 dan Rp. 60.449.655.086 untuk tahun 2013 dan mendapat realisasi dari pajak perhotelan sebesar Rp.5.929.938.014 pada tahun 2014, dan Rp.10.355.439.068 pada tahun 2015. Jadi, kontribusi yang diberikan pajak perhotelan untuk PAD Kota Mataram secara berturut-turut sebesar $12,79 \%$ dan $17,13 \%$. Pada tahun 2016 PAD Kota sebesar Rp.66.971.429.671, artinya meningkat dari tahun sebelumnya. Tetapi realisasi yang di berikan sebesar Rp. 10.791.412.715. jika di bandingkan dengan tahun sebelumnya, jumlah kontribusi yang diberikan Pajak Perhotelan untuk PAD Kota Mataram menurun menjadi $16.11 \%$. Namum pada tahun 2017 realisasi pajak perhotelan untuk PAD
Kota Mataram sebesar Rp.12.412.894.021 dari PAD yang meningkat sebesar Rp.66.267.245.420. Artinya kontribusi yang diberikan adalah $18.73 \%$ dari 9 sektor pajak yang ada.

Tabel Kontribusi PAD Kota Mataram Dari Sektor Pajak Restoran.

\begin{tabular}{|c|c|c|c|}
\hline Tahun & Jumlah PAD & Realisasi & $\%$ \\
\hline 2013 & 42.171 .198 .442 & 7.058 .184 .942 & 16.73 \\
\hline 2014 & 46.343 .206 .065 & 7.525 .423 .164 & 16.23 \\
\hline 2015 & 60.449 .655 .086 & 9.603 .797 .073 & 15.88 \\
\hline 2016 & 66.971 .429 .671 & 10.831 .060 .378 & 16.17 \\
\hline 2017 & 66.267 .245 .420 & 11.438 .711 .582 & 17.26 \\
\hline Jumlah & $\mathbf{2 8 2 . 2 0 2 . 7 3 4 . 6 8 4}$ & $\mathbf{4 6 . 4 5 7 . 1 7 7 . 1 3 9}$ & $\mathbf{1 6 . 4 6}$ \\
\hline
\end{tabular}

Dari tabel di atas, menunjukkan bahwa

kontribusi yang diberikan pajak restoran untuk PAD Kota Mataram tidak stabil yang artinya mengalami penurunan dan peningkatan. Dari tahun 2013 realisasi pajak restoran sebesar Rp. 7.058.184.942 sehingga persentase kontribusinya sebesar $16.73 \%$ dari 9 sektor pajak yang ada. Pada tahun 2014 realisasi pajak restoran sebesar Rp. 7.525.423.164 dan kontribusinya sebesar $16.23 \%$. Namun pada tahun 2015 dari realisasi Rp. 9.603.797.073 memberikan kontribusi $15.88 \%$ yang artinya mengalami penurunan tetapi pada tahun 2016 sampai 2017 kembali mengalami peningkatan sampai mencapai persentase 16.17 dari $\mathrm{Rp}$. 10.831.060.378 tahun 2016 dan $17.26 \%$ dari Rp. 11.438.711.582 pada tahun 2017.

Tabel 4.3.3.3 Kontribusi PAD Kota Mataram Dari Sektor Pajak Hiburan

\begin{tabular}{|c|c|c|c|}
\hline Tahun & Jumlah PAD & Realisasi & $\%$ \\
\hline 2013 & 42.171 .198 .442 & 352.129 .000 & 0.83 \\
\hline 2014 & 46.343 .206 .065 & 398.541 .661 & 0.85 \\
\hline 2015 & 60.449 .655 .086 & 486.588 .295 & 0.86 \\
\hline
\end{tabular}




\begin{tabular}{|c|c|c|c|}
\hline 2016 & 66.971 .429 .671 & 721.642 .282 & 1.07 \\
\hline 2017 & 66.267 .245 .420 & 1.466 .622 .671 & 2.21 \\
\hline Jumlah & $\mathbf{2 8 2 . 2 0 2 . 7 3 4 . 6 8 4}$ & $\mathbf{3 . 4 2 5 . 5 2 3 . 9 0 9}$ & $\mathbf{1 . 2 1}$ \\
\hline
\end{tabular}

Sumber : Dinas Pendapatan Kota Mataram Tahun 2018 Pada tabel ini menunjukkan berbeda dengan tabel kontribusi dari pajak hotel dan restoran, tabel ini hampir menunjukkan peningkatan tanpa mengalami penurunan dari masing-masing tahun yakni $0.83 \%$ darri raelisasi Rp. 352.129.000 tahun 2013, $0.85 \%$ dari Rp. 398.541 .661 tahun 2014, $0.86 \%$ dari Rp. 486.588.295 tahun 2015, 1.07 \% dari Rp. 721.642.282 tahun 2016, 2.21 dari Rp. 1.466.622.671 tahun 2017.

Tabel 4.3.3.4 Kontribusi PAD Kota Mataram Dari Sektor Pajak Parkir

\begin{tabular}{|c|l|l|r|}
\hline Tahun & \multicolumn{1}{|c|}{ Jumlah PAD } & \multicolumn{1}{|c|}{ Realisasi } & $\%$ \\
\hline 2013 & 42.171 .198 .442 & 811.364 .886 & 1.92 \\
\hline 2014 & 46.343 .206 .065 & 395.712 .777 & 0.85 \\
\hline 2015 & 60.449 .655 .086 & 443.838 .886 & 0.73 \\
\hline 2016 & 66.971 .429 .671 & 587.903 .160 & 0.87 \\
\hline 2017 & 66.267 .245 .420 & 660.156 .990 & 0.99 \\
\hline Jumlah & $\mathbf{2 8 2 . 2 0 2 . 7 3 4 . 6 8 4}$ & $\begin{array}{l}\mathbf{2 . 8 9 8 . 9 7 6 . 6 9} \\
\mathbf{9}\end{array}$ & $\mathbf{1 . 0 2}$ \\
& & & \\
\hline
\end{tabular}

Sumber : Dinas Pendapatan Kota Mataram Tahun 2017

Tabel di atas menunjukkan raelisasi untuk pajak parkir terhadap PAD Kota Mataram mengalami tidak kestabilan kontribusi pada tahun 2013 yakni $1.92 \%$ dari Rp. 811.364.886 dan 0.85 \% dari Rp. 395.712 .777 tahun 2014, $0.73 \%$ dari Rp. 443.838.886 tahun 2015, $0.87 \%$ dari Rp. 587.903.160 tahun 2016, $0.99 \%$ dari Rp. 660.156.990 tahun 2017 .

\subsubsection{Kontribusi PAD Kota Mataram Setiap} Tahun

Kontribusi PAD Kota Mataram belum menemukan berapa persentasi yang diberikan terhadap PAD Kota Mataram pertahunnya. Oleh karnanya peneliti mencoba melampirkan data-data atau perhitungan persentasi kontribusi yang diberikan oleh pajak pariwisata dari pajak daerah pertahunnya. Berikut tabel hasil data kontribusi PAD Kota Mataram pertahunnya dari pajak pariwisata yang berunsur dari pajak daerah ( 9 sektor pajak).

Tabel Kontribusi PAD Kota Mataram Setiap Tahun melalui Pajak Pariwisata

\begin{tabular}{|c|c|c|c|}
\hline Tahun & Jumlah PAD & $\begin{array}{c}\text { Realisasi } \\
\text { Jumlah Pajak } \\
\text { Pariwisata }\end{array}$ & $\%$ \\
\hline 2013 & 42.171 .198 .442 & 13.186 .534 .581 & 31.26 \\
\hline 2014 & 46.343 .206 .065 & 14.247 .651 .616 & 30.74 \\
\hline 2015 & 60.449 .655 .086 & 20.890 .616 .322 & 34.55 \\
\hline 2016 & 66.971 .429 .671 & 22.932 .081 .535 & 34.74 \\
\hline 2017 & 66.267 .245 .420 & 25.978 .385 .264 & 39.20 \\
\hline Jumlah & $\mathbf{2 8 2 . 2 0 2 . 7 3 4 . 6 8 4}$ & $\mathbf{2 7 . 2 3 5 . 2 6 9 . 3 1 8}$ & $\mathbf{3 4 . 4 5}$ \\
\hline & \multicolumn{2}{|l|}{} & \\
\hline Sumber : Dinas Pendapatan Kota Mataram Tahun 2017 & & \\
\hline
\end{tabular}

Pada tabel di atas menunjukkan PAD dan kontribusi pajak pariwisata tahun 2013-2017. Tabel di atas menunjukkan PAD meningkat secara terusmenerus. Realisasi pajak juga semakin meningkat kecuali pada tahun 2014 yang menunjukkan efektifitas realisasi pajaknya menurun yakni dari $31.26 \%$ pada tahun 2013 menjadi 30.74\% tahun 2014. Pada tahun selanjutnya meningkat stabil dari tahun 2015 sebesar Rp.20.890.616.322; tahun 2016 sebesar Rp22.932.081.535; dan Rp.25.978.385.264 tahun 2017. Sehingga kontribusinya meningkat berturut-turut $34.24 \%, 34.74 \%$, dan menjadi $39.20 \%$ tahun 2017.

Dapat disimpulkan bahwa, empat dari sembilan sektor pajak daerah yakni pajak hotel, restoran, hiburan, dan pajak parkir yang dimana keempat pajak daerah tersebut di klasifikasikan menjadi pajak pariwisata memberikan kontribusi yang paling besar pada tahun 2017 yakni mencapai $39.20 \%$. Hal ini menunjukkan bahwa efektifnya kontribusi pajak pariwisata untuk PAD Kota Mataram karna mendekati capaian $100 \%$ dari 
seluruh pajak daerah untuk PAD Kota Mataram dari tahun 2013-2017.

Dari keempat pajak diatas, dapat diketahui bahwa pajak yang memberikan kontribusi paling banyak adalah hotel, selanjutnya restoran, tempat hiburan dan parkir. Seperti yang kita ketahui, masing-masing dari penghasil pajak tersebut, memiliki fungsi yang berbeda-beda.

Selain tempat untuk menginap, hotel juga memberikan fasilitas yang cukup memadai. Mulai dari tempat tidur yang nyaman, ruangan yang ber $A C$, hidangan makanan yang lezat, suguhan pemandangan yang indah dan lain sebagainya. Semuanya dapat dinikmati sesuai tarif yang sudah ditentukan. Semakin tinggi tarif yang kita ambil, maka semakin banyak fasilitas-fasilitas yang kita dapatkan. Setiap hotel, rata-rata memberikan tarif kamar paling rendah yakni berkisar Rp. 100.000 perhari dengan fasilitas yang biasa. Semakin lama menginap dan menginginkan fasilitas terbaik, maka akan semakin tinggi tarifnya.

Restoran sebagaimana yang kita tahu, merupakan tempat berbagai kuliner yang disuguhkan dengan baik dan lezat. Biasanya juga menyediakan kuliner-kuliner khas daerah setempat. Tarif yang ditentukan juga berbeda-beda, tergantung harga pasarannya. Makanan dalam kategori sayur, tentu akan lebih murah harganya dari makanan yang termasuk kategori daging ataupun seafood. Makanan dalam kategori sayuran, biasanya di tarifkan sekitar Rp. 15.000 per porsi. Daging akan lebih mahal berkisar Rp. 35.000. dan seafood berkisar Rp. 50.000 .

Salah satu tempat hiburan adalah bioskip. Bioskop merupakan tempat pemutaran film-film perdana. Biasannya pemutaran film di tempat ini diperuntukkan untuk film-film yang rattingnya tinggi. biasanya Penentuan tarif untuk satu kali pemutaram film berkisar Rp. 35.000, dan tarifnya akan meningkat pada weekend, berkisar Rp. Rp.50.000

Parkir merupakan tempat ditertibkannya kendaraan-kendaraan yang mengunjungi tempattempat tertentu. Tarif yang di tentukan dalam pemarkiran biasanya berkisar Rp. 1000 untuk kendaraan roda dua, dan Rp. 3000 - Rp. 5000 untuk kendaran roda empat.
Dari keempat penghasil pajak di atas, sangat mudah untuk menganalisis hasil kontribusinya,yakni Dengan kita menentukan jumlah pengunjung untuk masing-masing tempat. Jika kita menentukan pengunjung untuk setiap penghasil pajak berjumlah 10 orang, maka akan jelas terlihat urutan-urutan penghasil pajak dari yang paling besar dan yang paling kecil.

\section{Kendala-kendala dalam Peningkatan Pariwisata}

Dalam usaha pengembangan yang telah dilakukan oleh Dinas Pariwisata Dan Kebudayaan Kota Mataram ternyata masih ada terdapat hambatan yang dihadapi terutama dalam peningkatan obyek wisata. Hasil wawancara peneliti dengan pihak terkait adalah kurangnya kesadaran masyarakat akan kebersihan dan pemeliharaan. Masyarakat seringkali membuang sampah sembarangan, dan ini yang paling sering terjadi dilokasi obyek-obyek wisata serta kurangnya keinginan masyarakat untuk menjaga fasilitas yang di sediakan dalam obyek wisata tersebut.

solusi untuk kendala tersebut, diantaranya memberikan penyuluhan akan pentingnya lingkungan yang bersih. Serta pentingnya fasilitas dalam mendukung peningkatan tempattempatwisata. Dan terkait dengan itu, Dinas Kebersihan juga berperan dalam mengatasi kendala ini, dengan cara memperbanyak tong sampah di area obyek-obyek wisata, memberikan beberapa spanduk atau poster dalam memberitahukan secara tidak langsung tentang pentingnya kebersihan dan pemeliharaan lingkungan.

Dalam peningkatan kontribusi pajak tentunya terdapat kendala-kendala yang di hadapi pihak Dispenda adalah menurunnya minat wisatawan untuk mengunjungi pariwisata yang ada di kota mataram. Jika jumlah wisatawan menurun secara otomatis kontribusi pajak pariwisata akan menurun karna tinggi rendahnya kontribusi pajak pariwisata tergantung pada jumlah pengunjung wisatawan

Solusi dari kendala tersebut tentunya harus ada tindakan dalam meningkatkan kualitas segi fisik dari setiap obyek wisata, karna jika obyek wisata di indahkan maka tentunya peminatnya akan semakin meningkat. Dan untuk itu di perlukan kerja sama antara dinas-dinas yang terkait dalam pengelolaan pariwisata.

\section{Kesimpulan}


Untuk hambatan pengembangan pariwisata, dari wawancara peneliti pada pihak Dispenda, kendala yang dihadapi adalah kendala dari masyarakat sendiri, yakni kurangnya kesadaran akan kebersihan di semua obyek wisata yang ada. Masyarakat selalu membuang sampah di tempat yang mereka inginkan. Untuk mengatasi kendala tersebut, pihak Disbudpar melakukan penyuluhan tentang akan pentingnya lingkungan yang bersih. Dan terkait dengan itu, Dinas Kebersihan juga berperan dalam mengatasi kendala ini, dengan cara memperbanyak tong sampah di area obyek-obyek wisata".

1. Obyek wisata yang menjadi unggulan yaitu wisata alam yang dimana data kunjungan dapat di lihat dari penjualan tiket masuk yang mencapai 1000-2000 pengunjung dalam satu bulan, sedangkan obyek wisata non alam peneliti tidak menemukan data karna tidak di kenakannya tiket masuk pada obyek wisata non alam tersebut.

2. Kontribusi Pajak Pariwisata Terhadap Pad Kota Mataram yang di lihat Dari Sudut Pajak Daerah, Empat dari sembilan sektor pajak daerah yakni pajak hotel, restoran, hiburan, dan pajak parkir yang dimana keempat pajak daerah tersebut di klasifikasikan menjadi pajak pariwisata memberikan kontribusi yang paling besar pada tahun 2017 yakni mencapai 39.20\%. Hal ini menunjukkan bahwa efektifnya kontribusi pajak pariwisata untuk PAD Kota Mataram karna mendekati capaian $100 \%$ dari seluruh pajak daerah untuk PAD Kota Mataram.

3. Kendala yang dihadapi dalam peningkatan kontribusi melalui pajak pariwisata adalah menurunnya minat wisatawan untuk mengunjungi pariwisata yang ada di kota mataram. Jika jumlah wisatawan menurun secara otomatis kontribusi pajak pariwisata akan menurun karna tinggi rendahnya kontribusi pajak pariwisata tergantung pada jumlah pengunjung wisatawan.

Berdasarkan kesimpulan-kesimpulan dan implikasi di atas, maka penulis mengemukakan saran-saran sebagai berikut :

1. Dinas terkait, peneliti mengharapkan agar memperhatikan lebih lanjut tentang pengelolaan retribusi terutama dalam kepariwisataan dan khususnya setiap objek wisata, agar setiap retribusi dapat di perhitungkan dan digunakan dengan lebih baik dalam pengelolaannya. Peneliti juga mengharapkan dinas terkait untuk lebih memberi fasilitas-fasilitas yang lebih memadai dalam memenuhi kebutuhan masyarakat terutama dalam kepariwisataan.

2. Masyarakat, peneliti berharap kepada masyarakat untuk lebih sadar akan kebersihan lingkungan dalam hal lingkungan obyek wisata di masing-masing daerah serta lebih dapat memelihara serta menjaga fasilitas yang sudah di sediakan oleh pemerintah daerah untuk obyek wisata di masing-masing daerah.

\section{DAFTAR PUSTAKA}

Buku:

Andi, Prastowo. 2011. Metode Penelitian Kualitatif. Yogyakarta: Ar-Ruzz Media.

Basu, Swastha DH., Irawan. 2008. Manajemen Pemasaran Modern, EdisiKedua, Cetakan Ke tigabelas. Yogyakarta: Liberty Offset.

Effendy, Onong Uchjana. 2004. Teori Komunikasi. Bandung : PT. Remaja Rosdakarya.

Djam'an Satori dan Aan Komariah. 2013. Metode Penelitian Kualitatif. Bandung : Alfabeta.

Fandeli, Chafid. 2000. Pengusaha Ekowisata. Yogyakarta : Pustaka Pelajar.

Gamal Suwantoro.2004. Dasar-Dasar Pariwisata. Bandung : PT. Remaja Rosdakarya.

Moleong, Lexy Johannes. 2005. Metodologi Kualitatif Edisi Revisi. Bandung : PT. Remaja Rosdakarya

Pendit, Nyoman S. 2002. Ilmu Pariwisata Sebuah Pengantar Perdana. Jakarta: PT. Pradnya Paramita.

Rahman, Herlina. 2005. Pendapatan Asli

Daerah.Yogyakarta : Pustaka Pelajar. 
Ridwan. 2008. Cara Menggunakan dan Memakai Analisis Jalur (Path Analisis). Bandung : Alfabeta

Rozali Abdullah. 2000. Pelaksanaan Otonomi Luas dan Isu Federalism Sebagai Suatu Alternatif. Jakarta : Raja Grafindo Persada.

Sugiyono. 2013. Metode Penelitian Pendidikan (Pendekatan Kualitatif dan Kualitatif). Bandung : Alfabeta.

Warsito. 2001. Hukum Pajak. Jakarta : PT. Rajawali Grafindo Persada.

\section{Skripsi:}

Tri Wahyuni. 2007. Studi Tentang Pengembangan Pariwisata dalam Upaya Meningkatkan
Pendapatan Asli Daerah Kabupaten Banjarnegara. (Tidak ditebitkan).

\section{Undang-Undang:}

Undang-undang Republik Indonesia Nomor 9 Tahun 1990 Tentang Kepriwisataan.

Undang-undang Republik Indonesia Nomor 22 Tahun 1999 Tentang Pemerintahan Daerah.

Undang-Undang Republik Indonesia Nomor 32 Tahun 2004 Tentang Pemerintahan Daerah

Undang-undang Republik Indonesia Nomor 33

Tahun 2004 Tentang Perimbangan Keuangan Antara Pemerintah Pusat Dan Pemerintahan Daerah

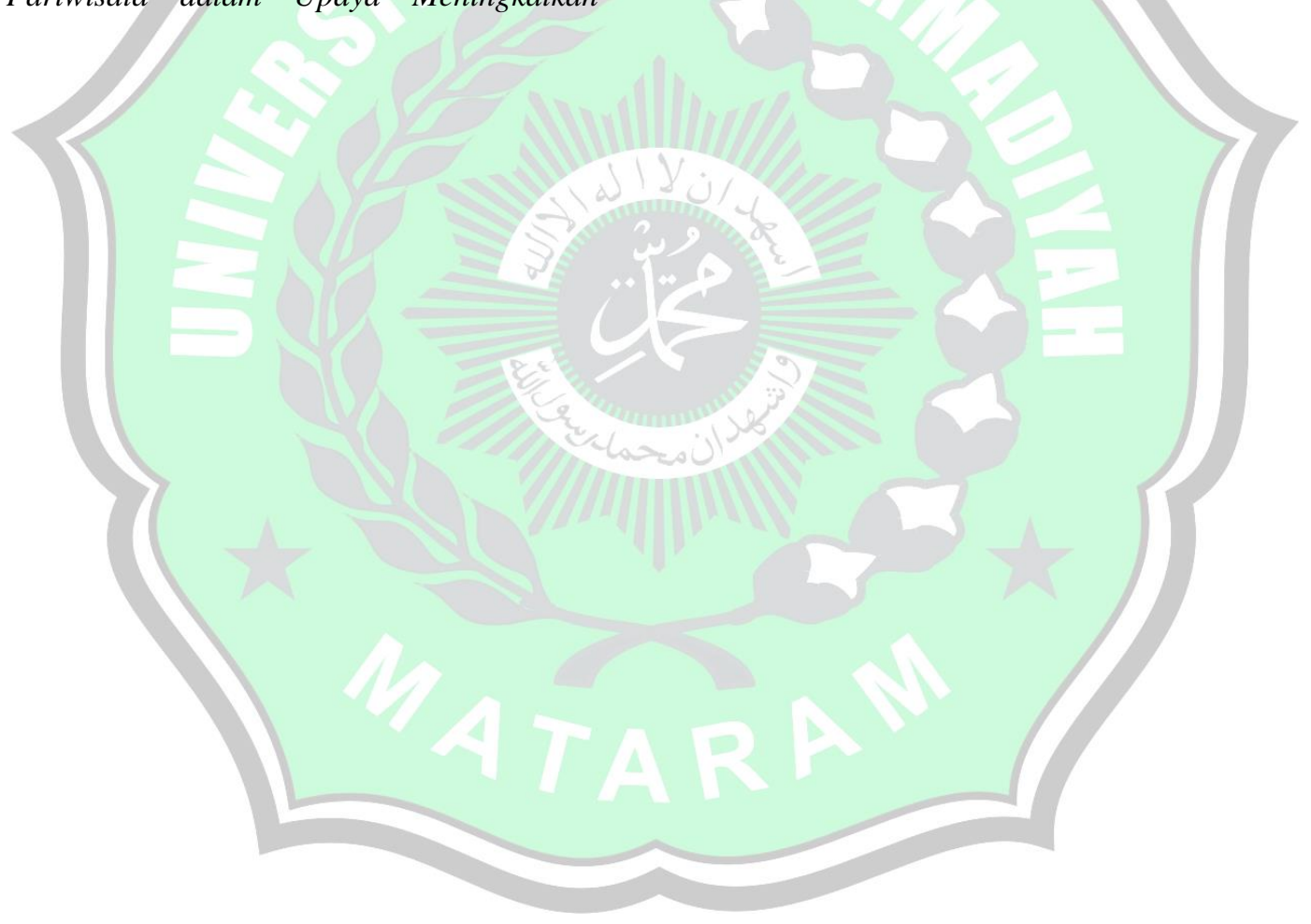

